\title{
KLASIFIKASI PEMAIN FUTSAL MENGGUNAKAN METODE SIMPLE MULTI ATTRIBUTE RATING TECHNIQUE (SMART)
}

\author{
Agus Budhi Marendra1); Didik Nugroho2); Iwan Ady Prabowo ${ }^{3)}$ \\ ${ }^{1,2,3)}$ Program Studi Teknik Informatika, STMIK Sinar Nusantara Surakarta \\ 1) agus.marendra10@gmail.com; ;) didikhoho@gmail.com; ${ }^{3)}$ Iwanadyp@gmail.com
}

\begin{abstract}
The development of futsal sports is currently very rapid. This can be seen from the many futsal clubs that have sprung up with very many members with the same average ability, making it difficult for a coach to determine the first team in the club. One of the uses of information technology is the use of a player's classification system for determining the main team in a futsal club. The method used to classify futsal players is a simple multi-attribute algorithm rating technique is chosen because this method can solve with many criteria or multi attributes besides that in this method also has a direct weighting technique that is more flexible because the user can change the criteria weight according to the level the desired interest, and this method will be applied to determine the players who registered in the recruitment of players who will enter the team and determine the core and reserve teams that will be brought to a competition. The data used in testing this system amounted to 30 player data obtained from the club's routine training. The results of manual data calculations with system calculations using the Simple Multi-Attribute Rating Technique (SMART) algorithm are the same results.
\end{abstract}

Keywords: Futsal, Recruitment, Simple Multi Attribute Rating Technique (SMART)

\section{PENDAHULUAN}

Futsal merupakan olahraga sepak bola mini yang dilakukan dalam ruangan dengan panjang lapangan 38-42 meter dan lebar 1525 meter dan dimainkan oleh 5 pemain. Futsal merupakan olahraga yang paling digemari dan sangat populer dikalangan remaja masa kini bahkan bisa dianggap cabang olahraga terpopuler [1].Dalam beberapa tahun terakhir, futsal sangat marak di Indonesia. Hal ini dapat dilihat dari banyaknya bermunculan klub-klub futsal yang memiliki banyak anggota dengan kemampuan bermain yang hampir rata. Hal ini membuat pelatih sering disusahkan dalam menentukan daftar nama pemain utama yang akan dibawa dalam suatu kejuaraan untuk mendapatkan hasil maksimal. Di tahun 2015 ada kurang lebih 30 pendaftar yang ingin masuk di tim MIRROR FC, sementara yang akan diterima masuk dalam tim hanya 10 orang pemain yang memiliki skill yang mumpuni serta fisik \& stamina yang kuat. Dari 10 orang pemain yang masuk dalam tim ini nantinya akan diseleksi kembali oleh pelatih untuk menentukan 5 pemain inti dan 5 pemain cadangan yang akan di bawa ke sebuah kompetisi. Inilah yang menjadi latar belakang penulis untuk mengusulkan pengembangan sistem pengklasifikasian yang nantinya dapat membantu seorang pelatih untuk memecahkan masalah dalam menentukan daftar nama pemain yang lolos seleksi dan daftar nama pemain yang akan dibawa ke sebuah kompetisi untuk mendapatkan hasil yang maksimal. Berbagai segi harus diperhitungkan untuk melakukan seleksi pemain dan meminimalisir tingkat kesalahan seorang pelatih dalam menentukan pemain yang dianggap layak dalam sebuah tim. Maka dari itu diperlukan sistem yang dapat memberi rekomendasi dengan menggunakan metode yang tepat. Sistem merupakan sekelompok elemen yang berinteraksi dengan maksud yang sama untuk mencapai suatu tujuan [2].Beberapa metode yang digunakan untuk Decision Support Sistem (DSS) diantaranya Simple Additive Weighting (SAW), Weighted Product (WP), Promethree, dan Simple Multi Attribute Rating Technique (SMART) [3].

Adapun penelitian yang dilakukan oleh Haris Eko Saputro dari Universitas Nusantara PGRI Kediri mengenai metode Simple Multi Attribut Rating Technique (SMART) yaitu sistem pendukung keputusan untuk rekomendasi velg variasi. Sistem ini bertugas untuk melakukan analisis velg yang menurut 
perhitungan cocok dengan kriteria untuk menentukan pembelian velg variasi terbaik yang nantinya akan diberikan rekomendasi kepada pembeli velg [4]. Penulis lebih memilih menggunakan metode Simple Attribute Rating Technique (SMART) karena metode ini dapat menyelesaikan dengan kriteria yang banyak atau multi attribute selain itu di metode ini juga memiliki teknik pembobotan secara langsung yang lebih fleksibel karena user dapat merubah bobot kriteria sesuai dengan tingkat kepentingan yang diinginkan. Diharapkan dengan adanya sistem ini, maka masalah penentuan pemain yang lolos seleksi pemain dan pemain yang masuk dalam tim utama dan cadangan dapat diatasi lebih cepat, tepat, dan akurat

\section{Rumusan Masalah}

Bagaimana merancang, membangun dan mengimplementasikan sistem klasifikasi pemain futsal menggunakan metode Simple Multi Atribut Rating Technique(SMART)

\section{Tujuan}

Tujuan dalam penelitian ini adalah merancang, membangun dan mengimplementasikan sistem klasifikasi pemain futsal menggunakan metode simple multi atribut rating technique(SMART).

\section{TINJAUAN PUSTAKA}

Futsal (futbol dalam bahasa spanyol yang berarti sepak bola dalam ruangan) merupakan permainan sepak bola yang dilakukan dalam ruangan. Olah raga ini sendiri dilakukan oleh lima pemain setiap tim berbeda dengan sepak bola konvensional dengan ukuran bola yang lebih kecil dan aturan permainan yang begitu ketat dari sepak bola. Selain itu, futsal adalah olah raga beregu yang sangat cepat dan dinamis [5]. Sedangkan menurut Murhanto futsal adalah permainan bola yang dimainkan oleh dua regu, yang masing-masing beranggotakan lima orang. Tujuannya adalah memasukkan bola ke gawang lawan, dengan memanipulasi bola dengan kaki [6].

SMART (Simple Multi - Attribute Rating Technique ) merupakan metode pengambilan keputusan multi kriteria yang dikembangkan oleh Edward pada tahun 1977. Teknik pengambilan keputusan multi kriteria ini didasarkan pada teori bahwa setiap alternatif terdiri dari sejumlah kriteria yang memiliki nilai - nilai dan setiap kriteria memiliki bobot yang menggambarkan seberapa penting ia dibandingkan dengan kriteria lain. Pembobotan ini digunakan untuk menilai setiap alternatif agar diperoleh alternatif terbaik.

SMART menggunakan linear additive model untuk meramal nilai setiap alternatif. SMART merupakan metode pengambilan keputusan yang fleksibel. SMART lebih banyak digunakan karena kesederhanaanya dalam merespon kebutuhan pembuat keputusan dan caranya menganalisa respon. Analisa yang terlibat adalah transparan sehingga metode ini memberikan pemahaman masalah yang tinggi dan dapat diterima oleh pembuat keputusan [7].

Model fungsi utiliti linear yang digunakan oleh SMART adalah seperti berikut :

Maximize $\sum_{j=1}^{k} w_{j}, u_{i j}, \forall i=1, \ldots, n \ldots$ (1)

Di mana :

- $\quad w_{j}$ adalah nilai pembobotan kriteria ke-j dari $k$ kriteria, $-u_{i j}$ adalah nilai utility alternatif $i$ pada kriteria $j$.

- Pemilihan keputusan adalah mengidentifikasi mana dari $\mathrm{n}$ alternatif yang mempunyai nilai fungsi terbesar.

- Nilai fungsi ini juga dapat digunakan untuk meranking $n$ alternatif

Teknik Metode SMART Adapun teknik atau langkah-langkah dalam proses SMART, antara lain:

1. Identifikasi user yang nantinya bertanggung jawab dalam mengambil keputusan.

2. Identifikasi Permasalahan yang ada Dengan melihat akar permasalahan dan batasan-batasan yang ada agar nantinya tidak menyimpang dari tujuan yang ingin dicapai.

3. Identifikasi alternatif yang ada untuk mencapai tujuan dari sistem yang akan dibuat.

4. Identifikasi kriteria-kriteria yang akan mendukung pengambilan keputusan

5. Memberikan peringkat atau bobot untuk setiap kriteria. Pemberian peringkat atau bobot ini ditentukan oleh user dan sistem akan memberikan bobot skala default dari peringkat yang dimasukkan.

6. Memberikan penilaian setiap kriteria untuk setiap alternatif. Juga dilakukan oleh user dimana penilaian setiap kriteria dapat 
bersifat kualitatif maupun kuantitatif untuk setiap alternatifnya.

7. Mengembangkan Single-Atribute Utilities yang mencerminkan seberapa baik setiap alternatif dilihat dari setiap kriteria. Tahap ini adalah memberikan suatu nilai pada semua kriteria untuk setiap alternatif dengan nilai yang berskala 0 sampai 1 .

8. Menghitung penilaian terhadap setiap alternatif

\section{METODE PENELITIAN}

1. Tahapan Pengumpulan Data

Langkah dalam teknik pengumpulan data melalui :
a. Teknik Observasi
b. Teknik Wawancara
c. Teknik Studi Literatur

\section{Tahapan Pengolahan Sistem}

Analisi Data Yang Digunakan Melalui Perancangan sistem dari Usecase diagram, activity diagram, sequence diagram, dan class diagram.

\section{Tahapan Pengembangan Sistem}

Tahapan Ini menentukan rancangan sistem yang akan dibuat, berdasarkan desain dan analisis sistem, perancangan ini meliputi :
a. Analisa
b. Desain sistem
c. Kontruksi / pengkodean
d. Pengujian Sistem
e. Implementasi

\section{A. Uji Fungsionalitas}

Pengujian black box berfokus pada pengujian persyaratan fungsional perangkat lunak, untuk mendapatkan serangkaian kondisi input yang sesuai dengan persyaratan fungsional suatu program.

\section{B. Uji Validitas}

Uji Validitas membandingkan antara hasil program yang dibuat sama dengan hasil perhitungan manual. Uji validitas ini dilakukan tiap tahap proses perhitungan sehingga akan terlihat bahwa program yang dibuat sesuai dengan algoritma yang digunakan.

\section{HASIL DAN PEMBAHASAN \\ 1. Penerapan SMART}

Berikut adalah langkah langkah contoh kasus Penerapan Metode Simple Multy Attribut Rating Technique (SMART) terhadap klasifikasi Pemain Futsal.

A. Menentukan jumlah kriteria dan sub kriteria

Kriteria yang dipakai dalam klasifikasi pemain futsal ada 8 kriteria yaitu nilai stamina, nilai fisik, nilai serang/attack, nilai passing/umpan, nilai skil, nilai bertahan, nilai reflek, nilai mental, dan untuk sub kriteria dari kriteria tersebut. Kriteria dan Sub Kriteria klasifikasi pemain ditunjukkan pada tabel 1.

Tabel 1. Kriteria dan Sub Kriteria klasifikasi pemain

\begin{tabular}{|c|c|c|}
\hline $\begin{array}{l}\text { Ko } \\
\text { de }\end{array}$ & $\begin{array}{c}\text { Nama } \\
\text { Kriteria }\end{array}$ & sub kriteria \\
\hline K1 & $\begin{array}{c}\text { Nilai } \\
\text { Stamina }\end{array}$ & $\begin{array}{l}\text { Sk1: lari putaran lapangan } 12 \\
\text { menit } \\
\text { Sk2: Lari Bolak Balik } \\
\text { Sk3: Lari Cepat } \\
\text { Sk4: Vo2max }\end{array}$ \\
\hline $\mathrm{K} 2$ & $\begin{array}{l}\text { Nilai } \\
\text { fisik }\end{array}$ & $\begin{array}{l}\text { Sk1: Tinggi Badan } \\
\text { Sk2: Berat Badan } \\
\text { Sk3: Kekuatan Otot } \\
\text { Sk4: Kelincahan } \\
\text { Sk5: Keseimbangan } \\
\text { Sk6: Push Up }\end{array}$ \\
\hline K3 & $\begin{array}{l}\text { Nilai } \\
\text { Attack }\end{array}$ & $\begin{array}{l}\text { Sk1: Kekuatan Tendangan } \\
\text { Sk2: Membongkar Pertahanan } \\
\text { Lawan } \\
\text { Sk3: Tendangan Arah Ke } \\
\text { gawang } \\
\text { Sk4: Penempatan Posisi } \\
\text { Sk5: Teknik Tendangan }\end{array}$ \\
\hline K4 & $\begin{array}{l}\text { Nilai } \\
\text { Umpan }\end{array}$ & $\begin{array}{l}\text { Sk1: Akurasi Umpan } \\
\text { Sk2: Umpan Lambung } \\
\text { Sk3: Umpan silang } \\
\text { Sk4: Umpan dengan kaki dalam } \\
\text { Sk5: Umpan dengan Kaki Luar } \\
\text { Sk6: Menciptakan Peluang }\end{array}$ \\
\hline K5 & $\begin{array}{l}\text { Nilai } \\
\text { Skils }\end{array}$ & $\begin{array}{l}\text { Sk1: Dribling Kaki Dalam } \\
\text { Sk2: Dribling Kaki Luar } \\
\text { Sk3: Kemampuan Lewati } \\
\text { Musuh } \\
\text { Sk4: Teknik Menerima Bola } \\
\text { Sk5: Penyelesaian } \\
\text { Sk6: Mencari Ruang }\end{array}$ \\
\hline K6 & $\begin{array}{c}\text { Nilai } \\
\text { Bertaha } \\
\text { n }\end{array}$ & $\begin{array}{l}\text { Sk1: Menghentikan serangan } \\
\text { lawan } \\
\text { Sk2: kekuatan body } \\
\text { Sk3: penjagaan lawan } \\
\text { Sk4: membaca permaianan } \\
\text { Sk5: disiplin dalam bertahan }\end{array}$ \\
\hline K7 & $\begin{array}{l}\text { Nilai } \\
\text { Reflek }\end{array}$ & $\begin{array}{l}\text { Sk1: Membaca Arah Bola } \\
\text { Sk2: Kecepatan Bergerak } \\
\text { Sk3: Kemampuan Power Play } \\
\text { Sk4: Membaca Serangan } \\
\text { Musuh } \\
\text { Sk5: Menghentikan Tendangan } \\
\text { Sk6: Kemampuan Split } \\
\text { Sk7: Reflek }\end{array}$ \\
\hline K8 & $\begin{array}{l}\text { Nilai } \\
\text { Mental }\end{array}$ & $\begin{array}{l}\text { Sk1: Percaya Diri } \\
\text { Sk2: Fokus Dalam Permainan }\end{array}$ \\
\hline
\end{tabular}




\begin{tabular}{|c|c|l|}
\hline $\begin{array}{c}\text { Ko } \\
\text { de }\end{array}$ & $\begin{array}{c}\text { Nama } \\
\text { Kriteria }\end{array}$ & \multicolumn{1}{c|}{ sub kriteria } \\
\hline & & Sk3: Berani Mengolah Bola \\
& & $\begin{array}{l}\text { Sk4: Kerja sama tim } \\
\text { Sk5: Komunikasi }\end{array}$ \\
& & Sk6: Ketenangan \\
\hline
\end{tabular}

B. Menentukan Bobot Setiap kriteria Untuk menentukan bobot kriteria pemain, pelatih menentukan bahwa bobot yang paling tinggi adalah nilai stamina fisik dan mental, sedangkan nilai serang, umpan, skils, bertahan, reflek dibuat sama bobotnya, sedangkan untuk sub kriteria tidak dilakukan perbedaan pembobotan, yaitu setiap sub kriteria bobotnya sama. Pembobotan Kriteria ditunjukkan pada tabel 2

Tabel 2 Pembobotan Kriteria

\begin{tabular}{|l|l|l|}
\hline Kode & Kriteria & Bobot \\
\hline K1 & Stamina & 15 \\
\hline K2 & Fisik & 15 \\
\hline K3 & Tendangan & 10 \\
\hline K4 & Umpan & 10 \\
\hline K5 & Skils & 10 \\
\hline K6 & Bertahan & 10 \\
\hline K7 & Reaksi & 10 \\
\hline K8 & Mental & 20 \\
\hline \multicolumn{2}{|c|}{ Total Bobot } & 100 \\
\hline
\end{tabular}

C. Normalisasi Bobot Kriteria

Rumusnya $\frac{w_{j}}{\sum w_{j}}$

Keterangan :

$w_{j} \quad$ : Bobot suatu kriteria

$\sum w_{j} \quad:$ Total bobot semua kriteria.

Normalisasi Bobot Kriteria ditunjukkan pada tabel 3

Tabel 3 Pembobotan Kriteria

\begin{tabular}{|r|l|r|}
\hline No & \multicolumn{1}{|c|}{ Kriteria } & \multicolumn{1}{c|}{ Bobot } \\
\hline K1 & Stamina & 0.15 \\
\hline K2 & Fisik & 0.15 \\
\hline K3 & Tendangan & 0.1 \\
\hline K4 & Umpan & 0.1 \\
\hline K5 & Skils & 0.1 \\
\hline K6 & Bertahan & 0.1 \\
\hline K7 & Reaksi & 0.1 \\
\hline K8 & Mental & 0.2 \\
\hline
\end{tabular}

\begin{tabular}{|l|c|c|}
\hline No & Kriteria & Bobot \\
\hline \multicolumn{2}{|c|}{ Total Normalisasi Bobot } & 1 \\
\hline
\end{tabular}

D. Menghitung Nilai Utility

Hitung nilai utility untuk setiap kriteria masing-masing.

$$
u_{i}\left(a_{i}\right)=100 \frac{\left(C_{\max }-C_{\text {out } i}\right)}{\left(C_{\max }-C_{\min }\right)} \%
$$

Keterangan :

$u_{i}\left(a_{i}\right)$ : nilai utility kriteria ke-1 untuk kriteria ke-i

$C_{\max }$ : nilai kriteria maksimal

$C_{\min }$ : nilai kriteria minimal

$C_{\text {out } i}$ : nilai kriteria ke-i

Untuk menentukan penilaian kriteria di sistem klasifikasi pemain futsal ini, ada 5 nilai utility yaitu $A, B, C, D$ dan $E$ untuk perhitunganya adalah sebagai berikut:

Penentuan Cmax dan Cmin nilai Utility ditunjukkan pada tabel 4

Tabel 4 penentuan Cmax dan Cmin nilai Utility

\begin{tabular}{|l|l|r|}
\hline \multirow{2}{*}{$\mathrm{nb}:$ nilai utility } & $\mathrm{Cmax}$ & 10 \\
\cline { 2 - 3 } & $\mathrm{cmin}$ & 1 \\
\hline
\end{tabular}

a. Nilai utility $A$

$$
\begin{aligned}
A: u_{i}\left(a_{i}\right) & =100 \frac{\left(c_{\max }-c_{\text {out } i}\right)}{\left(c_{\max }-c_{\min }\right)} \% \\
& =\frac{(10-1)}{(1-10)} * 100 \\
& =100
\end{aligned}
$$

b. Nilai utility $B$

$$
\text { B: } \begin{aligned}
u_{i}\left(a_{i}\right) & =100 \frac{\left(c_{\max }-c_{\text {out } i}\right)}{\left(c_{\max }-c_{\min }\right)} \% \\
& =\frac{(10-28)}{(1-10)} * 100 \\
& =80
\end{aligned}
$$

c. Nilai utility $\mathrm{C}$

$$
\text { C: } \begin{aligned}
u_{i}\left(a_{i}\right) & =100 \frac{\left(c_{\max }-c_{\text {out } i}\right)}{\left(c_{\max }-c_{\min }\right)} \% \\
& =\frac{(10-3.5)}{(1-10)} * 100 \\
& =70
\end{aligned}
$$

d. Nilai utility $D$

$$
\text { D: } \begin{aligned}
u_{i}\left(a_{i}\right) & =100 \frac{\left(c_{\max }-c_{\text {out } i}\right)}{\left(c_{\max }-c_{\min }\right)} \% \\
& =\frac{(10-4.6)}{(1-10)} * 100 \\
& =60
\end{aligned}
$$


e. Nilai utility $\mathrm{E}$

$$
\text { E: } \begin{aligned}
u_{i}\left(a_{i}\right) & =100 \frac{\left(c_{\max }-c_{\text {out } i}\right)}{\left(c_{\max }-c_{\min }\right)} \% \\
& =\frac{(10-5.5)}{(1-10)} * 100 \\
& =50
\end{aligned}
$$

E. Menghitung Nilai Akhir

Untuk menghitung nilai akhir langkah nya yang pertama adalah menghitung nilai sub kriteria, maka diperoleh nilai $A, B, C, D$ atau $E$ setelah itu nilai dikonversi, jika A maka nilainya 100 , jika B maka nilainya 80 , jika C maka nilainya 70 , jika $D$ maka nilainya 60 , dan jika E maka nilainya 50. Setelah nilai sudah dikonversi kemudian nilai kriteria dikalikan dengan nilai normalisasi bobot sesuai dengan kriterianya. Setelah itu nilai setiap kriteria ditambahkan maka diperoleh nilai akhir, berikut contoh perhitungan nilai pemain dengan metode SMART ditunjukkan pada tabel 5 .

Tabel 5 contoh perhitungan SMART
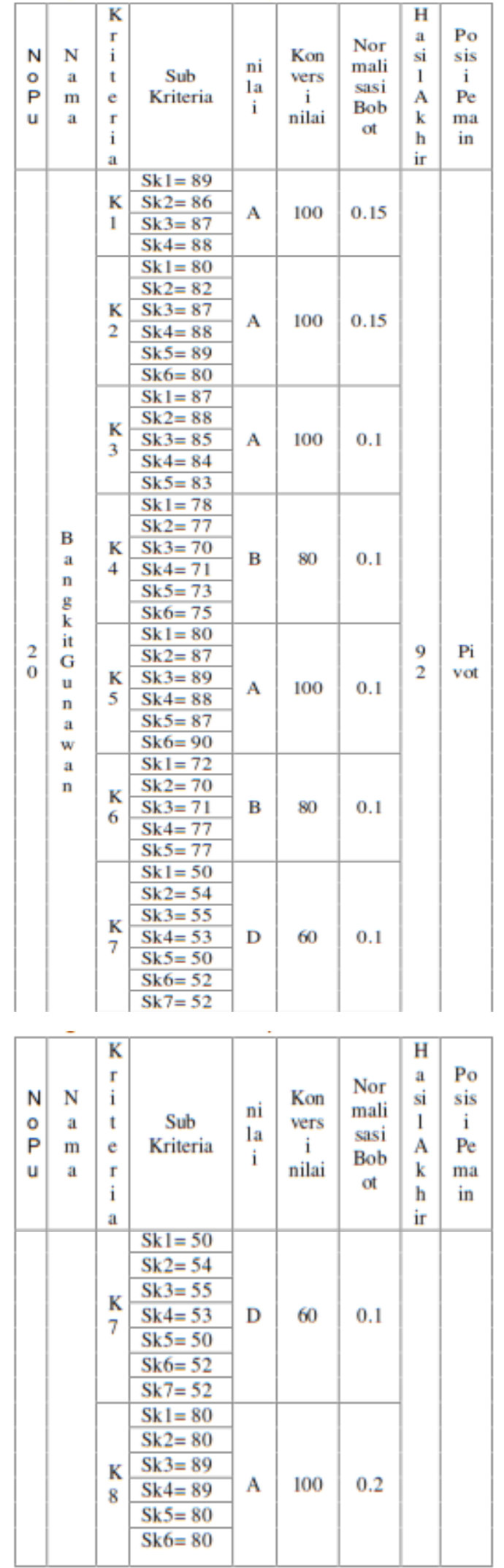

Sedangkan untuk menentukan posisi pemain, pelatih punya kriteria sendiri yaitu jika nilai $\mathrm{K} 3$ dan $\mathrm{K} 5$ lebih besar dari $\mathrm{K} 4, \mathrm{~K} 6, \mathrm{~K} 7$ maka posisi pemain berada di pivot / pemain depan, jika nilai $\mathrm{K} 4$ dan $\mathrm{K} 5$ 
lebih besar dari K3,K6,K7 maka posisi pemain berada di flank atau pemain samping, jika nilai $\mathrm{K} 6$ lebih besar dari $\mathrm{K} 4, \mathrm{~K} 5, \mathrm{~K} 6, \mathrm{~K} 7$ maka posisi pemain berada di Deffend / pemain belakang, jika nilai K7 lebih besar dari K3,K5,K4,K6 maka posisi pemain berada di penjaga gawang.

\section{Desain Sistem}

Dalam pembuatan sistem klasifikasi pemain futsal, penulis menggunakan alat bantu yang digunakan untuk desain sistem yang meliputi Usecase diagram, Activity diagram, Sequence diagram, Class diagram.

\section{A. Use Case Diagram}

Use Case diagram menggambarkan hak akses serta aktivitas yang dapat dilakukan oleh aktor admin data, yakni mengubah bobot kriteria, mengelola data pemain, mengelola nilai pemain, melakukan proses seleksi.

Use Case diagram hak akses serta aktivitas yang dapat dilakukan oleh aktor admin data dapat dilihat pada gambar 1.

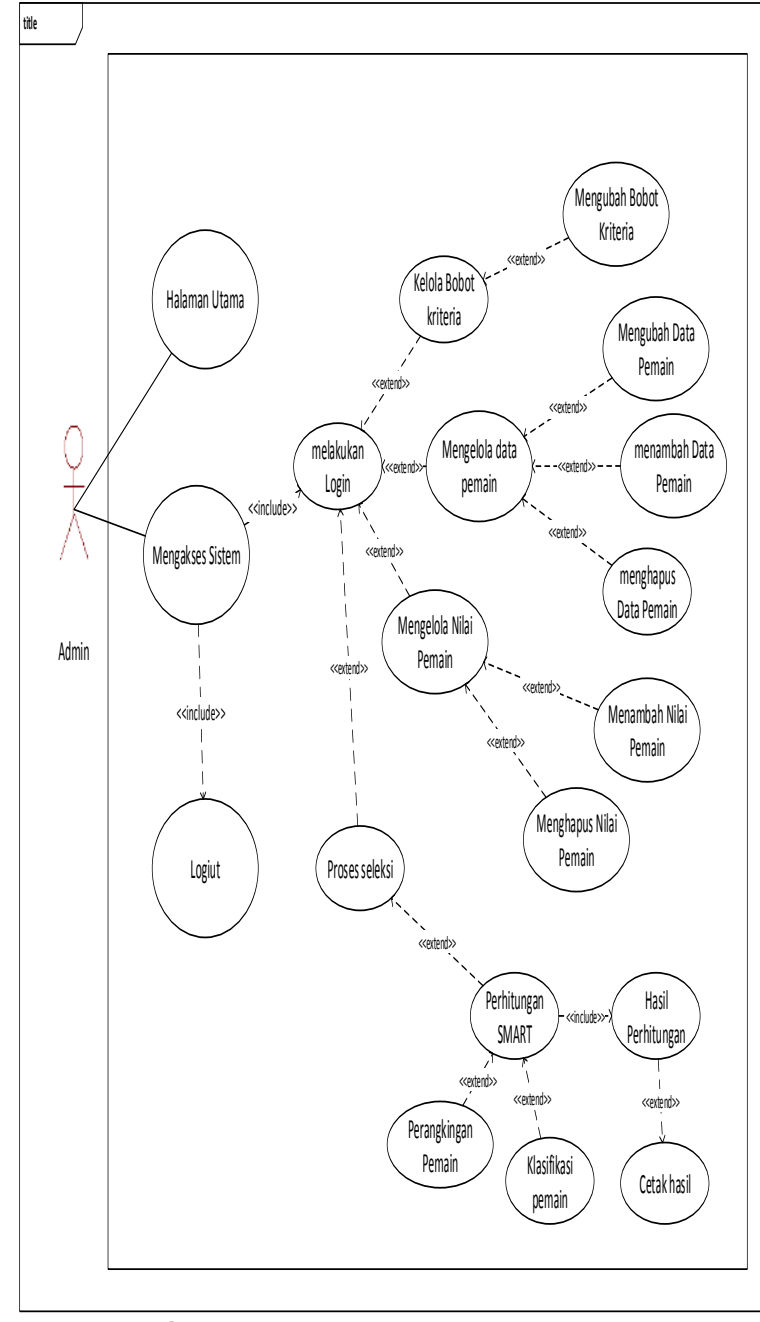

Gambar 1 Usecase diagram

\section{B. Activity Diagram}

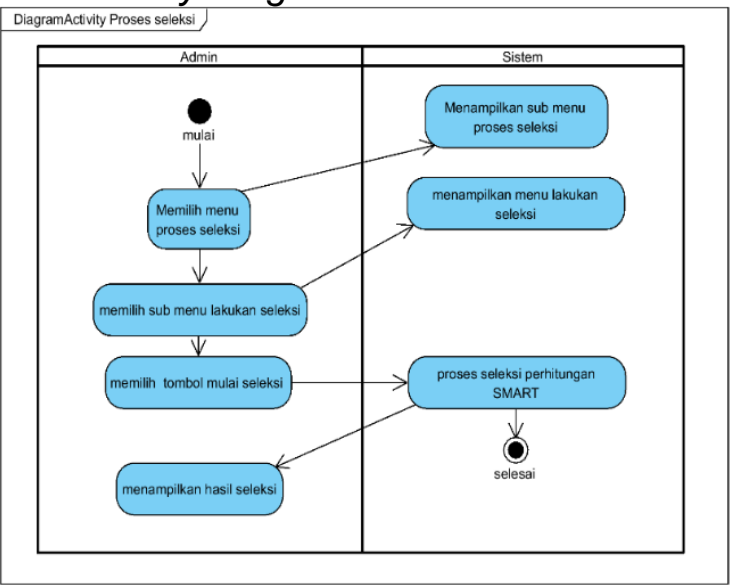

Gambar 2 Activity Diagram

Gambar 2 adalah gambar yang menjelaskan activity diagram mengelola data Nilai pemain, kemudia dilakukan proses konversi nilai dari setiap kriteria, dan kemudian dari hasil konversi nilai tersebut dikalikan dengan normalisasi bobot dari setiap kriteria, maka akan diperoleh nilai akhir dari setiap pemain, 
dan kemudian dilakukan perangkingan untuk menentukan pemain inti dan cadangan.

\section{Sequence Diagram}

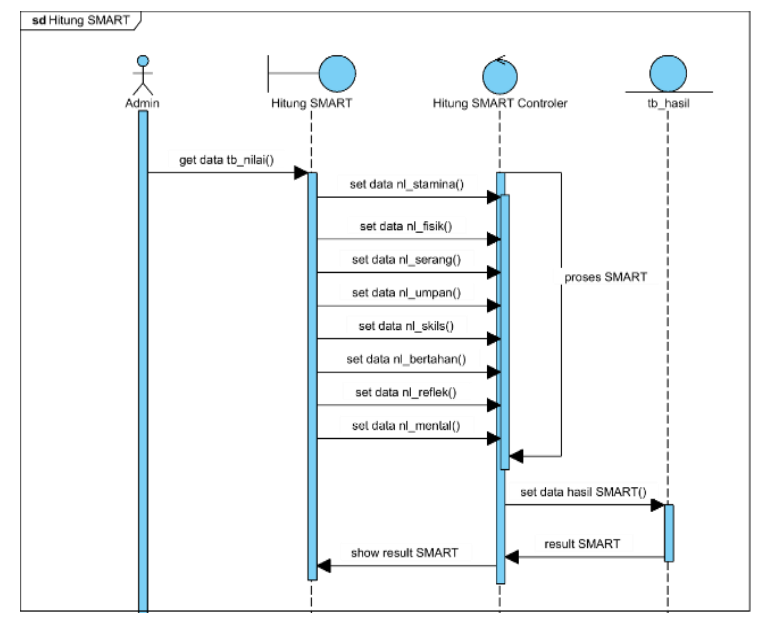

Gambar 3 Sequence Diagram

Gambar 3 dapat dilihat oleh admin sistem. Pada sequence diagram diatas admin sistem melakukan pengambilan data nilai dari table nilai, kemdian diproses pada SMART controller yang mengambil data dari database table nilai kemudian hasilnya ditampilkan kembali pada tampilan halaman proses seleksi.

\section{Class Diagram}

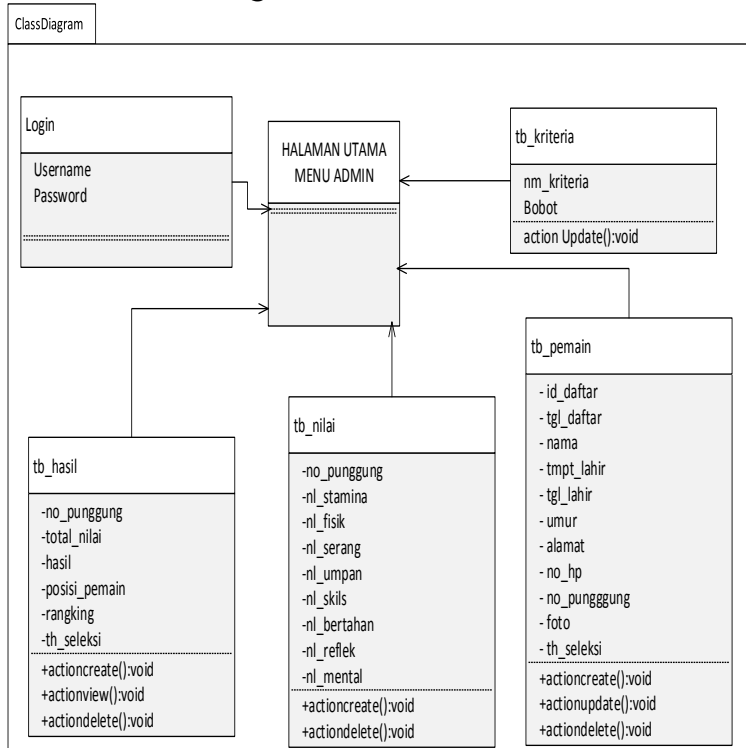

Gambar 4 Class Diagram

Gambar 4 menjelaskan table apa saja yang diperlukan dalam pembuatan sistem klasifikasi pemain futsal . selain berisi fieldfield dalam class diagram juga terdapat action yang akan terjadi dalam sistem.

\section{Implementasi Antarmuka}

Aplikasi ini memiliki antar muka berupa tampilan desktop. Tampilan utama program ditunjukkan pada gambar 5 .

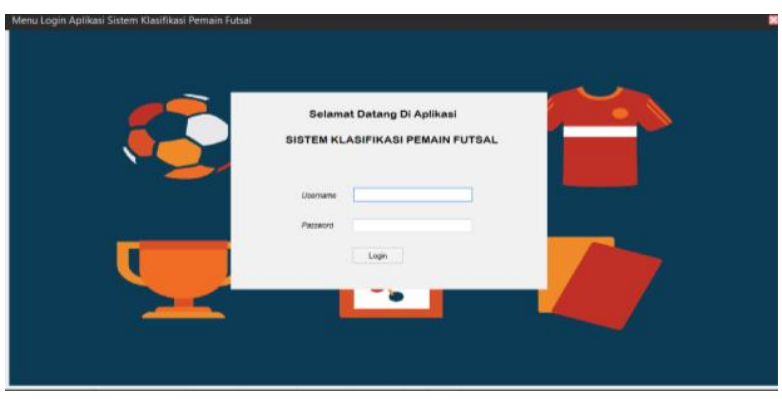

Gambar 5 Halaman Login

Tampilan halaman utama setelah admin data login ditunjukkan pada gambar 6 .

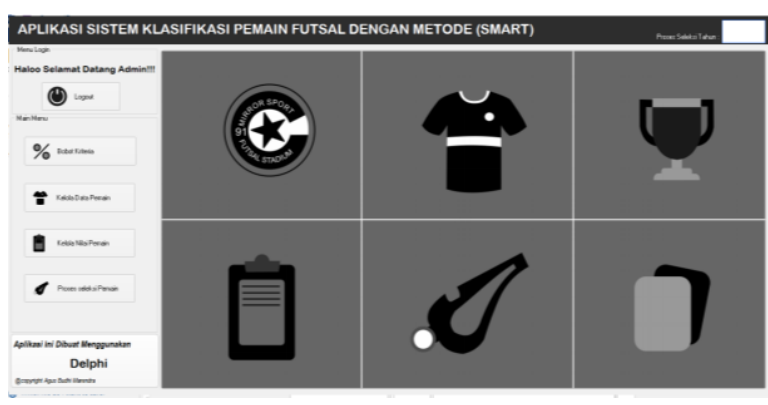

Gambar 6 Halaman Utama

Tampilan halaman untuk admin edit bobot kriteria ditunjukkan pada gambar 7 .

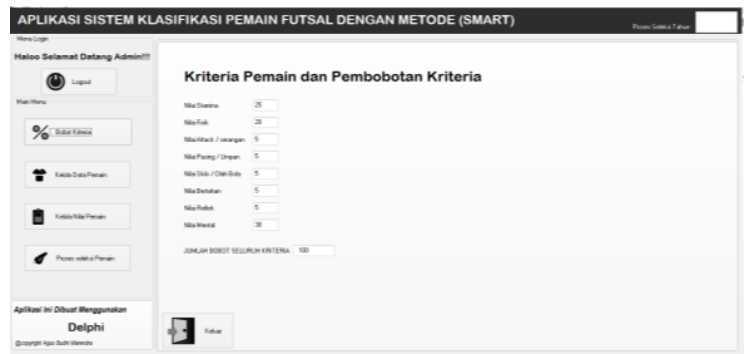

Gambar 7 Halaman edit bobot

Tampilan halaman untuk admin input data pemain ditunjukkan pada gambar 8 .

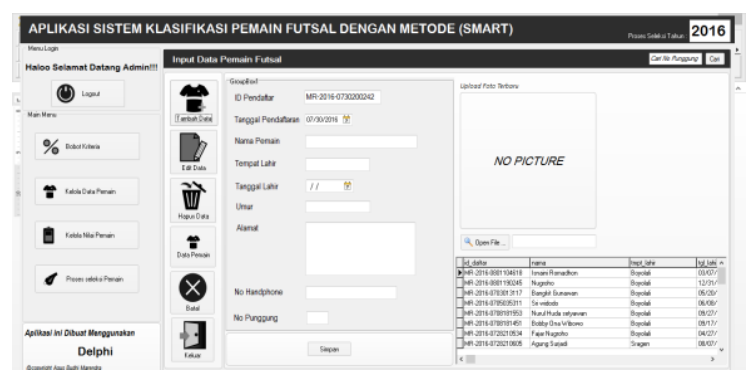

Gambar 8 Halaman Input Data 
Tampilan halaman untuk admin input data nilai ditunjukkan pada gambar 9 .

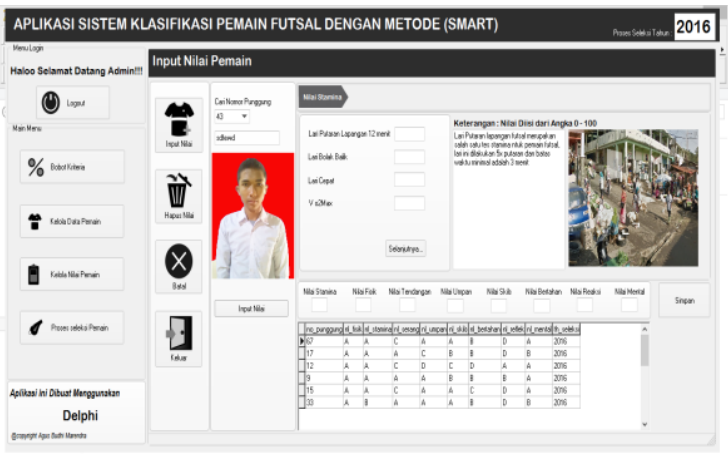

Gambar 9 Halaman Input Nilai

Tampilan halaman proses seleksi untuk perhitungan nilai pemain yang sudah diinputkan ditunjukkan pada gambar 10 .

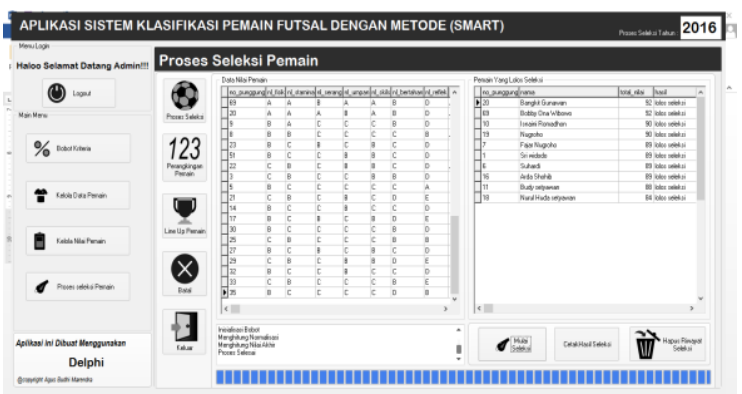

Gambar 10 Halaman Proses Seleksi

Tampilan halaman perangkingan pemain berdasarkan posisi pemain yang sudah diproses sistem ditunjukkan pada gambar 11 ..

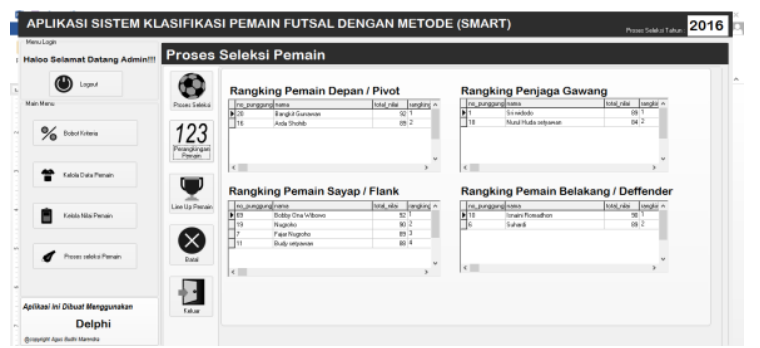

Gambar 11 Halaman Perangkingan

Tampilan halaman penentuan pemain inti dan cadangan ditunjukkan pada gambar 12 ..

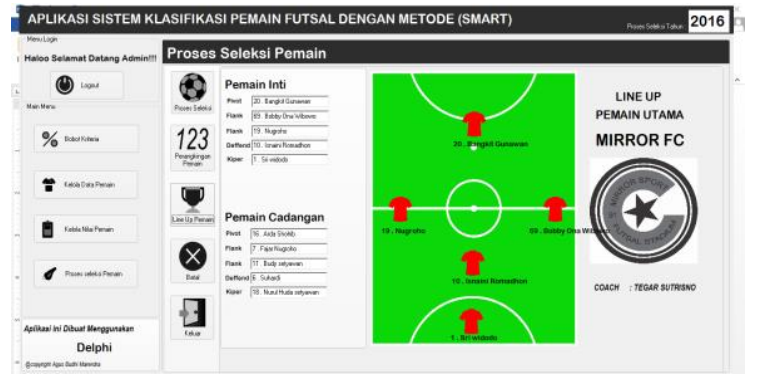

Gambar 12 Halaman line up pemain

\section{Pengujian Sistem}

a. Berdasarkan hasil pengujian dengan menggunakan pengujian fungsionalitas (black box) yang telah dilakukan pada kelima fungsi diatas yang meliputi fungsi login, fungsi kelola bobot kriteria, fungsi kelola data pemain, fungsi kelola nilai pemain, fungsi proses seleksi pada sistem klasifikasi pemain futsal ini, maka dapat ditarik kesimpulan bahwa aplikasi klasifikasi pemain futsal ini telah berjalan cukup optimal, hal ini dapat ditunjukan melalui menu-menu yang telah berjalan sesuai fungsionalnya.

b. Berdasarkan hasil pengujian dengan menggunakan pengujian validitas yang telah dilakukan pada sistem klasifikasi pemain futsal ini maka, dapat ditarik kesimpulan bahwa sistem klasifikasi pemain futsal ini sudah valid. Hal ini dapat ditunjukan melalui hasil nilai $\mathrm{V}$ antara perhitungan manual dan perhitungan sistem hasilnya adalah sama.

\section{PENUTUP}

\subsection{Kesimpulan}

Pada akhir laporan skripsi ini saya telah uraikan dan membahas permasalahan yang terjadi pada "klasifikasi pemain futsal menggunakan metode Simple Multi Attribute Rating Technique (SMART), dimana sesuai dengan perumusan masalah dan pembatasan masalah yang saya sampaikan sebelumnya maka saya dapat menarik kesimpulan sebagai berikut Dalam Penelitian yang telah dilakukan metode Simple Multy Attribute Rating Technique (SMART) telah berhasil diterapkan untuk mengklasfikasikan pemain futsal. Aplikasi sistem klasifikasi pemain futsal ini berhasil membantu pelatih untuk menentukan posisi pemain dan memilih pemain yang layak untuk dibawa kesebuah kompetisi.

\subsection{Saran}

Sistem Klasifikasi Pemain futsal di tim mirror fc dapat memberikan alternative pemain yang layak dibawa kesebuah kompetisi dengan menggunakan metode algoritma Simple Multy Attribute Rating Technique (SMART). Diharapkan dalam penelitian selanjutnya dapat mengembangkan aplikasi yang lebih spesifik dalam penentuan pemain futsal, contoh melakukan penelitian untuk menentukan penjaga gawang di team futsal, yang nantinya dapat memperoleh hasil yang maksimal dalam penentuan pemain. 


\section{DAFTAR PUSTAKA}

[1] R. Hatta, Teknik Permainan Futsal, 2003.

[2] I. A. Prabowo, "Sistem Informasi Penerimaan Peserta Didik Baru SMA Negeri 1 Ngemplak Kabupaten Boyolali," Jurnal IImiah SINUS, vol. 13, no. 2, pp. 65-82, 2015.

[3] Riza, M. Hasbi and I. A. Prabowo, "Sistem Pendukung Keputusan Penanganan Pasien UGD Menggunakan Metode Fuzzy Multiple Attribute Decision Making Dengan Simple Additive Weighting Pada Puskesmas Gajahan Surakarta," TIKomSiN, vol. 6, no. 1, pp. 21-28, April 2018.

[4] H. E. Saputro, "Sistem Pendukung Keputusan Rekomendasi Velg Variasi Menggunakan Metode SMART (Simple Multy Attribut Rating Technique)," Universitas PGRI Kediri, 2016.

[5] J. Laksana, Taktik dan Strategi Futsal Modern, Depok: Penebar Swadaya Group, 2011.

[6] Murhananto, Dasar-Dasar Permainan Futsal, Jakarta: Kawan Pustaka, 2006.

[7] A. Setyawan, "Sistem Pendukung Keputusan Pemilihan Mahasiswa Berprestasi Menggunakan Metode SMART", Skripsi, Prodi Sistem Informasi, Universitas Nusantara PGRI Kediri, 2015. 